\title{
Trust, morality and altruism in the donation of biological material: the case of Portugal
}

\author{
Susana Silva ${ }^{\mathrm{a}}$ and Helena Machado ${ }^{\mathrm{a}, \mathrm{b} *}$ \\ ${ }^{a}$ Research Center for the Social Sciences, University of Minho, Portugal; ${ }^{b}$ Center for \\ Social Sciences, University of Coimbra, Portugal
}

\begin{abstract}
This paper examines a number of social, ethical and cultural issues related to the application of biotechnology. The focus of the paper relies on two different cases of governing biotechnology in Portugal, referring to donation of biological material: the act of donation of eggs and sperm; and volunteers for donation of DNA material for the forensic national DNA database. We analyze the discourses on donation of biological material framing them in rhetorical devices of gift, altruism, informed consent and social responsibility. This comes blended with still unclear and emergent regulation and policies of access, retention, preservation and governing of biological material and of donors' identification. The risks are mitigated by narratives of science and technology as social progress and providers of public good and health benefits, as well as by underlining the individual responsibility in this domain and by reinforcing the rhetoric of gene quality, based on socio-cultural and bio-genetic criteria.
\end{abstract}

Keywords: donation of human biological material; quality and safety; altruism

\section{Introduction: the rhetoric of quality and safety}

This paper intends to question the normative contents and moral meanings that frame the construction of a technical-genetic project surrounding the donation of human biological material. We argue that such phenomena could give rise to the creation of multiple inequalities in terms of power, property and citizens' interactions with biotechnology based on the analysis of the act of donation of gametes to medical genetic databases and in the context of the constitution of the forensic national DNA profiles databases for forensic purposes through the collection of samples from volunteers. These two sorts of biobanks show an interesting analogy and common rhetorical devices in the sense that public good, individual rights and responsibilities, altruistic motivation of donors and informed consent are being framed.

Similarly to other European countries, the dominant discourses in Portugal surrounding the donation of gametes and of DNA samples for civil and criminal

\footnotetext{
*Corresponding author. Email: hmachado@ics.uminho.pt
} 
identification purposes are located in a wider political and governmental strategy of detection, prevention and reduction of illnesses, and of crime prevention, deterrence and combat. These arguments may contribute towards the limitation of citizens' chances to question or criticize them, in the sense that they reinforce the public trust in medicine and law by emphasizing their potential present and future benefits for everyone and their efficient and disinterested contribution to elimination of illness, crime and insecurity. In the context of eggs and sperm donation, as well as in the context of giving samples for inclusion in DNA profiles databases for civil and criminal identification purposes, the political discourses are supported by narratives of science and technology as social progress (Rose 2001) and as providers of public good and health benefits (Williams and Schroeder 2004). This collection of practices poses a challenge to traditional regulation in the ways it depends on the reconciliation of political demands of protecting science and public interest, whereas public trust is the key measure of political success or failure (Jones and Salter 2003). New forms of regulation of the donation of human biological material engender a public sense of confidence in medicine and technology, but need to incorporate answers to their risks and uncertainties in order to guarantee the citizens' trust in the promises of quality and safety of the genetic databases and the intentions and practices of those who hold the power to collect and use genetic information in the context of medical and forensic applications (Williams et al. 2004).

The announcement of the Portuguese Council of Ministers of 24 April 2008, regarding a law proposal which intends to transpose into the internal legal framing the European regulations concerning the donation, procurement, testing, processing, preservation, storage and distribution of human tissues and cells, reaffirmed the importance of guaranteeing high quality safety standards on appropriate technical and laboratory measures and on scientific and organizational requirements, circumscribed to the harmonization and international standards (Portuguese Council of Ministers 2008). This document also outlines the ethical and moral principles that should guide the human biological material donation programs - no payment, but altruism, solidarity, equity, transparency, accessibility and anonymity ${ }^{1}$ the latter is variable according to particular national characteristics associated with their respective legal and juridical framing.

In his speech during the public announcement of the law proposal regarding the forensic DNA profiles database on 1 June 2007, the Portuguese Justice Minister stressed the advantages of science in the service of justice, as a way to make forensic procedures faster, more accurate, precise and trustworthy. Concurrently, a justice allied with science should be more prepared to serve the public good, in possession of the means to find out more effectively the real offenders and to acquit the wrongly accused (Portuguese Justice Minister 2007). It also stressed the quality of scientific and laboratorial proceedings, assured by global mechanisms of technological harmonization, and always in view of a logic of transparency of procedures and respect for the confidentiality of data and individual rights. This 
political rhetoric also presents the creation of a forensic DNA profiles database as an indispensable step towards the democratic consolidation of citizenship and as a civilizational advance for Portuguese society, henceforth further included in the ensemble of the more developed societies. The technology of identifying individuals through DNA profiles is thus configured as a socio-technical instrument which serves the purposes of a sort of moral landscape associated with scientific development and the benefits of the articulation between justice and technology, on the one hand, and with the protection of society from the threat of crime, on the other (Cutter 2005).

These narratives highlight the importance of the voluntariness in the donation of human cells and promote the notion that the knowledge of the genetic profile is fundamental for security, well-being and personal identities, giving rise to several strategies that aim to maintain ontological relationships between the human cells and their donors, in technical, moral and legal terms (Pennings 1997, Ploeg 2002, Sheldon 2005, Thompson 2005, Donovan 2006). Both cells and donors are more and more subjected to an extensive medical, social, sexual, familial and genetic evaluation (e.g. Barratt et al. 1998, Waldby 2000, Borrero 2002, Soini et al. 2006 ) with the main stated objective of guaranteeing quality control, which is supposed to ensure health and security for present and future human generations, in a context of transforming human cells into medical goods (Tober 2001, Barney 2005) and instruments of "biosurveillance" (Williams and Johnson 2004). The cultural work of making the "truth" of genetics and biology meanings as a source of personal identity and human relatedness is supported by the social images of techno-science as objective, rational and disinterested; to geneticize identity and genealogy naturalizes the truth (Nash 2004) and, at the same time, it combines the socialization of the public understanding of science with the biologization of the social values (Franklin 2006); that is, the process of learning scientific culture and how to live within it reinforce the idea that social values have biological grounds.

The concern with the quality, safety, effectiveness and efficiency of the scientific and police investigations and of the clinical and laboratorial practices that in some way deal with human biological material is framed in a socio-cultural and politicalideological context where, over the last three decades, medicine, justice, science and technology have been confronted with a sort of legitimacy crisis (Habermas 1970, Beck 1992). Several social and professional groups have responded to this not only through claims of quality and safety, but also through the emphasis on social responsibility and on the democratization of decision-making and debate processes (e.g. Vayena et al. 2002, Land and Evers 2003, Soini et al. 2006, Nuffield Council on Bioethics 2007). The good practices, the purification of laboratorial environment and human cells, and the protocols in absolute conformity with law and ethics and the national, European and international regulations, appear as elements that may contribute towards the leveling of biotechnologies and nature, in the way they must be added to techno-medical practices in order to ensure the reliability of biological material (Franklin 2006). 
Through the analysis of the recruitment processes of egg donors, sperm donors and volunteers we intend to show how the legal admissibility of reproductive cells (eggs and sperm) donation and of the collection of DNA material from volunteers for forensic purposes are articulated with their respective medical and political uses. The rhetoric of gametal quality and safety of DNA profiles databases encourages the social construction of gift, altruism, free and informed consent of the citizens and their social responsibility, supported by biotechnology, on the elimination of illness, prevention of crime and guarantee of security. The organization of these projects of potential donors of human biological material evidences an individual focus of informed consent and responsibility, while attention to the duties pertaining to the custodians of such biological banks and to the institutions that fund them is missing (Williams and Schroeder 2004). They include tacit and powerful narratives by which a political community makes binding collective choices and produces and validates collective knowledge and public trust (Jasanoff 2005).

Empirically, we adopt a multidimensional perspective, of qualitative and interpretative type, grounded on the following sources of information: the law of assisted reproductive technologies (Law no. 32/2006 of 26 July) and the law concerning the national DNA profiles database for civil and criminal identification purposes (Law no. 5/2008 of 12 February); interviews conducted with experts that were part of the commission appointed by the Minister of Justice which prepared the law proposal for the DNA profiles database; information available in the websites of two non-public centers for reproductive medicine that recruit egg donors and/or semen donors in Portugal; and news articles published in the national press about the intentions to create the first egg and sperm public bank in this country. First, we reflect on the complex configurations and the moralization of "biocitizenship" as a concept which describes the multiple and complex processes by which groups and individuals are involved and reconstruct their identities in their encounters with biotechnology as a technology per se, but also as information and a source of power (Rose and Novas 2005), in the latter case as a set of rights and duties associated with forms of surveillance and social control based on the scientific and technological knowledge of human cells. Secondly, we analyze the complexity of the modes of intersection between the diverse biogenetic, socio-cultural, political-ideological and juridical-legal meanings underlying the selection and scrutiny mechanisms of potential donors and volunteers.

\section{From the right of information to the duty of gratuitous and volunteer donation}

In a context in which the rhetoric of socio-political commitment is emphasized with the need to increase the number of births in Portugal, ${ }^{2}$ on one hand, and with the combat of crime and terrorism, on the other, the medical and political discourses around the law of assisted reproductive technologies and the law of the forensic national DNA profiles database may play a role in the promotion of the duty to 
participate in the reproduction of human beings and to cooperate with public security. This might form a moral landscape and act as an individual responsibility for the future collective well-being. The right to information aiming to provide informed consent may in this fashion be reconfigured into the moral duty to comply with medical and technical interventions on the cells and human bodies so that they may originate healthy children (Ettorre 2000, Silva 2008) and render an "objective" measure of individual identity. We intend to discuss the emergence of a new morality that "forces" the "good", healthy and altruistic citizen, to voluntarily and gratuitously give her/his eggs and sperm and to present the State with a sample of her/his own body as a gift for the common good (Rose and Novas 2005).

In the 18th article of the assisted reproductive technologies law the buying and selling of eggs and semen is prohibited. Hence, the law has no reference to the existence of any other modes of economic, reproductive and symbolic incentives that are used in Portugal in the context of gamete donation, namely: (a) the possibility to examine the donors' health exhaustively and gratuitously, testing, in particular, their respective reproductive capacity; and (b) the offering of economic and symbolic compensation to the donors for their gift (see Table 1). It is important to pay attention to the fact that the motives that lead someone to donate their gametes are multiple and complex and are not limited to financial and clinical incentives, to the possibility of helping someone, or the satisfaction for the display of altruism; the desire itself to disseminate the donor's own genes also represents a strong motivation for the donation of gametes, which may be accompanied by a potential reward associated with the establishing of bonds regarding the born children without having to assume legal responsibilities (Tober 2001).

The main advantage of such rewards is the fact that they don't pervert the moral significance of gamete donation, while reinforcing the normative principles of quality, safety and gratuitousness in this domain. However, the offering of a complete and exhaustive study of the donor's reproductive health may stand as a new form of perpetuation of inequalities in terms of power and property relations (Inhorn and Balen 2002, p. 15, Plows and Boddington 2006), by contributing to the allurement of women and men whose economic, social and cultural resources might not allow them to access such kind of possibilities without having to resort to gamete donation.

The female donors do not receive a gratitude certificate nor compensation for the inconvenience caused which are given to the male donors, but rather compensation for the treatment they are submitted to (Haimes and Luce 2006). There is an underlying gender ideology to this distinction, which promotes egg donation as a duty, as opposed to the donation of semen, seen as a benefit for which there should be symbolic gratitude for the inconvenience caused for men. ${ }^{3}$ The dominant idea that it is a woman's duty to cooperate in egg donation programs is also extended to other domains, as in the fact that the woman should understand her altruistic attitude, which seems to be associated with the acceptance of treatment risks, supposedly minimal and tolerable: 
Table 1. Some modes of incentive used in gamete donation in Portugal.

\begin{tabular}{|c|c|c|}
\hline & Egg donors & Sperm donors \\
\hline $\begin{array}{l}\text { Economic and } \\
\text { symbolic } \\
\text { compensation }\end{array}$ & $\begin{array}{l}\text { - "The majority of donors feel very } \\
\text { accomplished for the fact that they } \\
\text { have the chance to help an infertile } \\
\text { couple to start a family with the } \\
\text { birth of a much desired child."1 } \\
\text { "The woman also receives from } \\
500 \text { to } 750 \text { euro as a } \\
\text { compensation for the treatment } \\
\text { that she will be submitted to."4 }\end{array}$ & $\begin{array}{l}\text { "This act [sperm donation] is } \\
\text { economically compensated for } \\
\text { the inconvenience caused." }\end{array}$ \\
\hline $\begin{array}{l}\text { Gratuitous and } \\
\text { exhaustive health } \\
\text { evaluation }\end{array}$ & $\begin{array}{l}\text { - "In order to be accepted in the egg } \\
\text { donation program, they will be } \\
\text { submitted to a reproductive system } \\
\text { check-up ... which will provide us } \\
\text { with valuable information } \\
\text { regarding the donor's fertility, her } \\
\text { health status, and a specialized } \\
\text { evaluation concerning their } \\
\text { potential for motherhood, greater } \\
\text { than any other woman who would } \\
\text { want to get pregnant on her own } \\
\text { would get.".2 }\end{array}$ & $\begin{array}{l}\text { "The donation of semen is a } \\
\text { voluntary act by which a healthy } \\
\text { man, with optimum semen quality, } \\
\text { makes a gift of gametes." } 3\end{array}$ \\
\hline
\end{tabular}

Source: ${ }^{1}$ http://www.avaclinic.pt/doacao.htm;

${ }^{2}$ http://www.ivi.es/prt/pacientes/ovocitos.htm;

${ }^{3}$ http://www.ivi.es/prt/pacientes/semen.htm;

${ }^{4} \mathrm{http}: / /$ www.correiomanha.pt/comentario.asp?idCanal=0\&id=208125 [Accessed 6 May 2008].

It is very important that the donor gets the far reaching aim of her altruistic attitude. She must understand and accept the treatment's risks. ... It is a process in which the risks are minimum and tolerable. (AVA Clinic 2008)

The women shall then accept the duty to altruistically sacrifice themselves for the sake of motherhood, which implies, in the case of egg donation, the (re)production of the sense of positive acceptance of pain and uncertainty, the participation in several sorts of biomedical intervention and the naturalization of risks (Becker and Nachtigall 1994, Lupton 1999).

The rights to freedom, autonomy and privacy may thus be transformed into the duty to consent to the risks involved in the gamete donation procedures. In the end, altruism may emerge as a "transcendent quality" of especially feminine gametes, as a "secondary commodity" (Marx 1995 [1867]) whose valuation intends to sell the quality gametal product by redefining it as a gift (Mauss 1954), thus concealing the (re)production of unequal distribution of rewards, risks and responsibilities that is underlying to gamete donation (Haimes 1993, Haimes and Luce 2006).

According to article 6 of the law of the DNA profiles database, the collection of volunteers' samples may only take place under a statement of "free, informed and 
written" consent, which symbolizes the transformation of cells into an object of knowledge and intervention and the reconfiguration of the relationship between the volunteer citizen and their biological material in a techno-scientific relation for forensic purposes. The sample is received by the State as a voluntary gift, transformable through biotechnology into the genetic identity of the volunteer in question, whose profile that is obtained in this manner may be cross-referenced with other types of files mentioned in the law - files of formal suspect profiles; of convicts; of professionals who conduct the collection and analysis of samples; and of dead bodies, parts of dead bodies or things found on crime scenes or civil identification sites (no. 3 of article 20 of Law no. 5/2008). The citizen issues a clear sign of confidence in the State and science by taking the initiative of addressing the proper institutions in writing, whether it's the Scientific Police, or the National Institute of Legal Medicine in order to donate a biological sample and consent to the inclusion of the respective DNA profile into the database created for civil and criminal identification purposes. This procedure serves the common good; at the same time it reinforces the individual sense of belonging to society and the motivation to participate in social cohesion and harmony by manifesting responsibility as a citizen in the fight against crime and in purposes of civil identification (victim and missing persons identification).

The law of assisted reproductive technologies asserts the confidentiality of nongenetic donor information, but we note several reconfigurations in the modes of access to information that is secret to begin with: for example, the revelation of the identity of the donor, who specifically allowed such information to be given to the person born with her/his gametes, in case she/he wants to know about a possible legal impediment to a prospective marriage, or upon ponderous reasons acknowledged by a judicial verdict (article 15, no. 1, no. 3 and no. 4 of Law no. $32 / 2006)$. The apparent guarantee of donor anonymity favors, in fact, the maintenance and potential solidification of social relations formed through gamete donation, by promoting the image of genes as a carrier of unique and unrepeatable information that distinguishes the individual and identifies her/him, but also as an element which fosters social and emotional connections, possibly distanced in time, as something that could be named "biosociality" (Rabinow 1997).

The risk of compression of the gamete donor's and the volunteer's individual rights and the uncertainties regarding some technical and scientific procedures, are softened or suppressed, without any discussion surrounding the possible modes of consent and certification of the participant's rights (Machado and Silva 2008). Some recent contributions suggest that informational consent is quite limited for most donors and quite insufficient to legitimize such collective projects (O’Neill 2002, Williams and Schroeder 2004).

\section{Processes of citizen's monitoring: "are we all potential donors"?}

In the preliminary text of Directive 2004/23/EC, concerning the establishment of norms for quality and safety regarding the donation of human biological 
material, it is acknowledged that the availability of human tissue, cells and organs depends on the existence of citizens willing to make donations, therefore highlighting the necessity to promote information and awareness campaigns at national and transnational levels based on the theme "we are all potential donors". However, the fulfillment of the apparent possibility that any citizen could become a biological material donor depends on the existence of some requirements. Above all, what we intend to show here is how the donor monitoring criteria display factors of biological and genetic sort, but overall socio-cultural, economic, moral and emotional, whose articulation is complex and heterogeneous, revealing some parallelisms between the body and the social structures (Featherstone and Turner 1995).

Article no. 6 of the forensic national DNA profiles database law regulates its gradual and phased construction from the collection of biological samples from volunteer citizens that, in a "free and informed" manner, agree to donate their "genetic fingerprint". According to the Portuguese law, "volunteer" citizens are not only the relatives of missing persons or unidentified victims, when it happens to be the case, but also anyone who wishes to donate a sample for entry in the national DNA database, where the Portuguese law configures the only case in Europe. ${ }^{4}$ The potential donors must address, in writing, their request for sample collection to the competent entities for laboratorial analysis of the respective samples (the Laboratory of the Scientific Police and the National Institute of Legal Medicine), which symbolically means the maximization of choice and sense of individual responsibility in the maintenance of social order by these citizens, who decide to donate their cells to the State so that these may be analyzed and integrated in a database which aims to combat criminality and to guarantee public security and tranquility. As for the formal suspects who donate samples for criminal investigation purposes they cannot be seen as volunteers. The construction of a forensic DNA profiles database in Portugal thus feeds on the idea that ordinary citizens' participation in it is needed and should be valued (Evans and Plows 2007). However, this sort of public participation fosters the increase of mandatory volunteerism as good citizenship (Marx 2006) which projects modes of reproduction of the social distinctions between the respectable law-abiding citizens - the "volunteers", on one hand, and the suspect citizens - seen as mandatory donors, on the other (Ploeg 2002).

In the 10th article of the assisted reproductive technologies law gamete quality guarantee is required in the donation of eggs and spermatozoa, which promotes an implicit distinction between those who should be reproduced - the healthy bodies - and those who should not be reproduced - the ill bodies (Ettore 2000). According to the information conveyed in the websites of two private clinics that recruit eggs and sperm donors in Portugal, as well as in the news articles about the recruitment strategies that the first Portuguese egg and sperm public bank would engage, ${ }^{5}$ the evaluation of gamete quality appears to depend not only on bio-genetic elements, but also on the social, cultural and moral 
characteristics of the donors, namely: (a) to exclude the woman or man with genetic and/or hereditary diseases, as well as those who have habits seen as unhealthy (tobacco, alcohol or drugs use); (b) the cariotype's normality and the adequacy of the reproductive system and/or gametes to the technical procedures they will eventually be submitted to; (c) to have optimum quality sperm, that is, "to be able to render samples with a total of 90 million spermatozoa with good motility, which implies 4.5 times more than what the World Health Organization considers to be normal" (IVI 2008); (d) egg donors will be required to be between 18 and 35 years old, and semen donors to be between 18 and 48 years old; (e) to have a relatively high educational level or to exercise a socially acknowledged occupation and, preferably, one that is valued; or (f) to display a voluntary and altruistic attitude (see Table 2). It seems that social, cultural and moral prerequisites (such as high educational levels, a valued occupation, a voluntary and altruistic attitude or healthy lifestyles) must be added to medical reasons (like the exclusion of those with genetic or hereditary diseases) behind the required donor characteristics in order to ensure optimum quality both of biological material and of medical practices in this domain. As Sarah Franklin notes:

quality assurance, not just technical assistance, is now the element that must be added to biology to make it as good as nature. ... Quality is about taking away the dirt, the noise, the pollution, the pathology and the "junk" that detract from the reliability of biological function. (Franklin 2006, pp. 171-172)

The scrutiny of donors' general health capital is managed by multiple and distinct forms: the quality female gametes are incorporated within healthy women from a medical, clinical and reproductive point of view, but also from a psychological and mental one; whereas the male gametes seem to be disincorporated by the evaluation of their quality mostly from their respective motility, freedom from genetic or hereditary diseases and from bacterial infection. The evaluation of the "health" characteristics of egg and sperm donors highlights a notion of motherhood which invokes elements of moral and emotional characterization and a notion of paternity mostly attached to bio-genetic factors (Haimes 1993, Machado 2008, Silva and Machado 2008). Also, the medical and technical procedures that egg donors are subjected to emerge as an opportunity to confirm their capacity for motherhood, since their gametes and reproductive system seem to be adequate for bio-genetic procreation, at the same time they prove their altruism and send a clear sign that their greatest wish is above all to have a child, a feeling that is to be shared among all healthy women. This contrasts with the far more measured account of male motivation for donation and reinforces the assumption that having children is a natural and inevitable part of a couple's life, in particular of being a woman (Phoenix et al. 1991, Ulrich and Weatherall 2000).

In short, gamete donors seem to correspond to a certain social profile apparently educated, altruistic and respectable, in good health and with healthy habits, characteristics that seem to reside in cells themselves (Tober 2001). The 


\section{S. Silva and H. Machado}

Table 2. Some characteristics of egg donors and semen donors in Portugal.

\begin{tabular}{|c|c|c|}
\hline & Egg donors & Semen donors \\
\hline $\begin{array}{l}\text { Good condition of } \\
\text { general health }\end{array}$ & $\begin{array}{l}\text { - "Women that are physically and } \\
\text { mentally healthy can donate eggs } \\
\text {.. The potential donors participate } \\
\text { in a rigorous medical, psychological } \\
\text { and clinical analysis evaluation } \\
\text { process." } \\
\text { - "Ovocyte donors must ... possess a } \\
\text { negative family history concerning } \\
\text { genetically transmitted diseases; } \\
\text { normal cariotype (chromosome } \\
\text { study); negative study for sexually } \\
\text { transmitted diseases ...; } \\
\text { reproductive system normality; } \\
\text { physical and mental health; } \\
\text { previous history of fertility and/or } \\
\text { adequate response to ovarian } \\
\text { stimulation treatment."2 }\end{array}$ & $\begin{array}{l}\text { - "In order to be a semen donor ... it } \\
\text { is necessary: ... to be physically } \\
\text { and psychologically well; not suffer, } \\
\text { neither the donor nor his direct } \\
\text { family, from serious genetic } \\
\text { dysfunctions or hereditary } \\
\text { diseases. ... To not suffer from } \\
\text { bacterial infections that can be } \\
\text { verified in blood, urine and semen } \\
\text { cultures. To have a semen quality } \\
\text { approximately } 4.5 \text { times better than } \\
\text { normal levels, and that can } \\
\text { adequately withstand the process of } \\
\text { freezing and unfreezing."3 }\end{array}$ \\
\hline Age & $\begin{array}{l}\text { - "Women between } 18 \text { and } 35 \text { years } \\
\text { old may become egg donors.", }\end{array}$ & $\begin{array}{l}\text { - "Donors must ... not be over } 48 \\
\text { years old." }\end{array}$ \\
\hline $\begin{array}{l}\text { Altruism and } \\
\text { voluntarism }\end{array}$ & $\begin{array}{l}\text { - "The donor's voluntary and altruistic } \\
\text { attitude helps many couples to fulfill } \\
\text { the dream of becoming parents and } \\
\text { allows the women receptors to } \\
\text { experience pregnancy and the birth } \\
\text { of a child."1 } \\
\text { " And it's possible thanks to the fact } \\
\text { that there are women who take part } \\
\text { in rigorous egg donation programs } \\
\text { in order to help other women who } \\
\text { have feelings just like them and } \\
\text { yearn above all for a child."2 }\end{array}$ & $\begin{array}{l}\text { - "The sperm bank ... includes the } \\
\text { possibility to accept men who are } \\
\text { willing to make a donation of their } \\
\text { semen samples in order to help } \\
\text { couples or women that, for some } \\
\text { reason or another, need it in order to } \\
\text { be able to have children.", }\end{array}$ \\
\hline Healthy lifestyles & \multicolumn{2}{|c|}{$\begin{array}{l}\text { - "Then, family history in terms of hereditary diseases and personal habits are } \\
\text { considered - "no alcohol, tobacco or drugs".,4 }\end{array}$} \\
\hline $\begin{array}{l}\text { Educational level } \\
\text { and/or } \\
\text { occupation }\end{array}$ & \multicolumn{2}{|c|}{$\begin{array}{l}\text { - "Donor recruitment is to be made 'in closed environment', starting with } \\
\text { informational sessions in each Faculty.... Then, professional associations and } \\
\text { unions will be contacted. Only later can it be widened to the general } \\
\text { population.", } \\
\text { - "The donation of genetic material ... is accepted from college students and } \\
\text { some liberal professionals, such as physicians, professors or architects, } \\
\text { among others, just as long as they are healthy.", }\end{array}$} \\
\hline
\end{tabular}

Source: ${ }^{1}$ http://www.avaclinic.pt/doacao.htm;

${ }^{2}$ http://www.ivi.es/prt/pacientes/ovocitos.htm;

${ }^{3} \mathrm{http}: / /$ www.ivi.es/prt/pacientes/semen.htm;

${ }_{5}^{4}$ http://jpn.icicom.up.pt/2006/07/13/up_abre_banco_de_esperma_e_ovulos_html;

${ }^{5} \mathrm{http}: / /$ www.correiomanha.pt/comentario.asp? $\overline{\mathrm{i}} \mathrm{dCanal}=\overline{0} \mathrm{\& id}=20 \overline{8} 1 \overline{2} 5$ [Accessed 6 May 2008]. 
gene is thus outlined as an element that connects corporeity and social spaces. The genetification is extensive and profound, and evidenced in the construction of kinship, individual identity and lifestyles (Ettore et al. 2006).

The biologization and ensuing moralization of citizenship stated in the enunciation of egg and semen donors' characteristics are thus projected into the political conceptualization of the volunteer figure in the donation of biological material for the civil and criminal identification database that we find in Law no. 5/2008 of 12 February. ${ }^{6}$ These are configured as co-constructors of the good functioning of the social system in its mission to ensure the identification of its citizens in danger situations (disappearances, catastrophes and crime victims) and in the protection from the threat of crime (particularly, the most violent crimes, such as terrorism and sexual crimes). The importance of protection and security in these circumstances assumes a sort of social and collective nature, which tends to be present in all individuals, but somewhat transcending them (Durkheim 1997 [1984]). The role of public trust in the success or failure of biobank projects is evidenced by the important function it fulfills in public discourse and politics. Public trust and support are obtained from the concepts and terminology that materialize those practices if they correspond with established narratives in a particular society (Prainsack 2007), such as crime and illness detection and prevention.

In interviews, the experts who were part of the commission that prepared the law proposal mentioned the theoretical possibility of the volunteer figure to appear in the set of risk occupations, more likely to be involved in disappearance events military, fishermen, firemen. However, the concept of volunteer equally serves the purpose of the moral projection of citizenship, assuming the outlines of an "ideal-type" (Weber 1962) of citizen, of a pure form of citizenship that might not find a match within empirical reality. The following interview excerpt perfectly illustrates the intent of the narratives collected:

We have started with a project for a universal database. Maybe, so that the idea isn't abandoned totally, we choose for now to talk about potential universality, that is, the State will allow any citizen to be a part of it. It has some ideological content, I mean, it's not just for criminals, for the thief, it's for anyone who wants to.

The idea of volunteerism as vital for the construction of a forensic DNA profiles database thus serves the purposes of a rhetoric that we find in the discourses of the experts who constituted the commission that prepared the law proposal for the forensic national DNA profiles database mentioned, but that are supposed to be shared by the collective conscience (Durkheim 1997 [1984]). This is in order to confer and adapt some sense into the political action of proposing that any citizen may submit a biological sample, without concerns, and contribute to a process of ideal formulation of citizenship and equal opportunities of social (re)rehabilitation, in this case being materialized in a forensic DNA profiles database of universalist and humanist orientation, which offers the potential of criminal non-discrimination, for it enables the inclusion of any - and every - citizen. 
The uses of biotechnology contribute, in the cases analyzed here, to the design of new forms of social division, classification and inequality based on "biological" aptitudes as elements of belonging to social groups and of elaboration of "imagined genetic communities" (Pálsson 2007), while outlining an implicit moral censure of certain behaviors and lifestyles seen as unhealthy. In the case of the selection of eggs and sperm donors, the "biological" material could be classified as belonging to bio-genetically, socially and emotionally healthy citizens on the one hand, and as ill or potential unwell on the other. These medical distinctions enunciate those who should be reproduced and those who are not supposed to be reproduced in the future. The construction of the forensic national DNA profiles database is based on two distinct groups of donors of biological material: suspects/criminals or "volunteers", the latter being the law-abiding and respectable citizens. The genetic and biological evaluations and the medical and technological monitoring have been articulated in a way that expands the frontiers of biocitizenship moralization, in so far as the assessment of quality and safety of biological material donation is being made progressively earlier. In this paper we show how this assessment, tracing back to the cells, tissues and technical procedures, and to the moral and ethical principles that guide the behaviors and values of the women and men that should become donors, may have theoretically unlimited impacts, although restricted at the present moment, showing once more that nature and society are not ontologically distinct entities (Lock et al. 2000). This co-production of the natural and the social stand in the way solutions are prescribed for the normative problems that confront us today regarding technology and might widen our awareness of alternative and possible socio-technical worlds (Jasanoff 2005).

\section{Conclusions}

In this article, some social, ethical, cultural and political dimensions of biocitizenship in Portugal were approached from the analysis of two distinct contexts of biological material donation: the medical context of gamete donation; and the forensic context of the constitution of national DNA profiles databases from volunteer donations. New forms of moralization were highlighted within a wider technicalgenetic project, grounded on the social construction of gift, altruism, informed consent and social responsibility.

In this political and social project of genetics and biotechnology we watch the establishment of several parallelisms between some donor characteristics and the dominant social, cultural and political order, which underlies the representation of human cells as transmission vehicles of simultaneously biogenetic, socio-cultural and emotional information. The inequalities and genetic (in)security inherent to the moralization of the concept of biocitizenship are naturalized through two discursive patterns: the softening or suppression of risks associated with biotechnology by emphasizing the rhetoric of gamete quality and the safety of genetic databases and by reaffirming the dominant conception of DNA as an objective measure of 
individual identity; and the purification, a discursive mechanism that stresses individual responsibility in the donation of biological material in order to achieve collective well-being - procreation and security, a task assisted by biotechnology.

The discursive imagery surrounding the donation of human biological material has been oriented by the principles of activity regulation and of juridical-scientific organization, with the absence of the incorporation of participation mechanisms and civic evaluations of the modes of social and political management of genetic data. The appraisal for quality, efficacy and safety of certain techniques and/or procedures results from contradictory and ambivalent processes that demand a multidimensional analysis that can account for the heterogeneity of knowledge and the dynamics of expectations, certainties and uncertainties raised by biotechnologies, often associated with matters of power and control, as well as matters of public confidence in social institutions, whether it's on a decision-making processes level, or in the control and monitoring of the results.

\section{Acknowledgements}

We would like to thank the Foundation for Science and Technology (Portuguese Ministry of Science, Technology and Higher Education) for financing this research through a PhD fellowship SFRH/BD/ 10396/2002 (2004-2008) and a post-doc fellowship SFRH/BPD/34143/2006 (2007-2010).

\section{Notes}

1. For a systematization of how data might be classified in terms of the degree of anonymity, see Williams and Schroeder (2004).

2. For the first time in the past 90 years, in 2007, the number of births in Portugal was lower than the number of deaths. Over the past decade the decline of births in Portugal became a matter of public debate and the political discourse highlighted the government's commitment and support regarding maternity and paternity in order to increase the number of births. For example, in November 2007, the Portuguese government made a public announcement of the assisted reproductive technologies regulation (the law was passed on July 2006) which emphasized the political expectations associated with this initiative: 1750 more births in Portugal as a result of reproductive technologies.

3. Rene Almeling's (2006) study about staff-donor interaction in the gendered organization of egg donation agencies and sperm banks in the United States demonstrates a complex mix of altruism and financial compensation by which women and men are coached differently about appropriate responses. The author discusses how commercial fertility agencies, in response to perceived client interests, highlight the female donor's altruism while accepting the male donor's financial interests.

4. This concept of volunteer is rather distinct from that which regulates police activity in the United Kingdom, in so far as in the latter, the collection of "volunteer" samples can be conducted massively and routinely or in the course of a criminal investigation, being aimed at a specific group of individuals (mass or intelligence led DNA screen).

5. The intended first Portuguese egg and sperm public bank was supposed to begin activities in September 2006, which didn't happen because the Portuguese Health Ministry demanded its suspension until the regulation of the assisted reproductive technologies. That law came into force on 11 February 2008 (Regulamentary Decree no. 5/2008), but according to information published in the press, the scientists in the University of Oporto that were involved since the 
beginning in that project, publicly announced in June 2008 their intention to give up on the installation of the first public center for egg and sperm collection in Portugal, unless the responsible politicians and/or the National Council on Assisted Reproductive Technologies would manifest their will to follow through.

6. Forensic DNA profiling and databasing in Portugal has a short history in so far as the law which regulates the national database for forensic purposes was only very recently published, in February 2008, and it will only start its effective functioning in 2009.

\section{References}

Almeling, R., 2006. Why do you want to be a donor? Gender and the production of altruism in egg and sperm donation. New Genetics and Society, 25 (2), 143-157.

AVA Clinic, 2008. AVA Clinic Website [online]. Available from: http://www.avaclinic.pt/doacao.htm [Accessed 6 May 2008].

Barney, S., 2005. Accessing medicalized donor sperm in the US and Britain: an historical narrative. Sexualities, 8 (2), 205-220.

Barratt, C., et al., 1998. Gamete donation guidelines. The Corsendock consensus document for the European Union. Human Reproduction, 13 (2), 500-501.

Beck, U., 1992. Risk society: towards a new modernity. London: Sage Publications.

Becker, G. and Nachtigall, R., 1994. "Born to be a mother": the cultural construction of risk in infertility treatment in the USA. Social Science and Medicine, 39 (4), 507-518.

Borrero, C., 2002. Gamete source, manipulation and disposition. In: E. Vayena, et al., eds. Current practices and controversies in assisted reproduction. Geneva: World Health Organization, $166-176$.

Cutter, A., 2005. To clear or to convict? The role of genomics in criminal justice. Genomics, Society and Policy, 1 (3), 1-15.

Donovan, C., 2006. Genetics, fathers and families: exploring the implications of changing the law in favour of identifying sperm donors. Social \& Legal Studies, 15 (4), 494-510.

Durkheim, E., 1997 [1984]. The division of labor in society. New York: The Free Press.

Ettorre, E., 2000. Reproductive genetics, gender and the body: "Please doctor, may I have a normal baby?" Sociology, 34 (3), 403-420.

Ettorre, E., et al., 2006. Feminism confronts the genome: introduction. New Genetics and Society, 25 (2), 135-142.

Evans, R. and Plows, A., 2007. Listening without prejudice? Re-discovering the value of the disinterested citizen. Social Studies of Science, 37, 827-853.

Featherstone, M. and Turner, B., 1995. Body \& society: an introduction. Body \& Society, 1 (1), 1-12.

Franklin, S., 2006. The cyborg embryo. Theory, Culture \& Society, 23 (7-8), 167-187.

Habermas, J., 1970. Technology and science as "ideology". In: J. Habermas, ed. Toward a rational society: student protest, science and politics. Boston: Beacon Press, 81-121.

Haimes, E., 1993. Issues of gender in gamete donation. Social Science and Medicine, 36 (1), 85-93.

Haimes, E. and Luce, J., 2006. Studying potential donor's views on embryonic stem cell therapies and preimplatation genetic diagnosis. Human Fertility, 9 (2), 67-71.

Inhorn, M. and Balen, F., eds., 2002. Infertility around the globe: new thinking on childlessness, gender and reproductive technologies. Berkeley: University of California Press.

IVI, 2008. Instituto Valerciano de Infertilidad Website [online]. Available from: http://www.ivi.es/ $\mathrm{prt} /$ pacientes/semen.htm [Accessed 6 May 2008].

Jasanoff, S., 2005. In the democracies of DNA: ontological uncertainty and political order in three states. New Genetics and Society, 24 (2), 139-155.

Jones, M. and Salter, B., 2003. The governance of human genetics: policy discourse and constructions of public trust. New Genetics and Society, 22 (1), 21-41. 
Land, J. and Evers, J., 2003. Risks and complications in assisted reproduction techniques: report of an ESHRE consensus meeting. Human Reproduction, 18 (2), 455-457.

Lock, M., et al., ed., 2000. Living and working with the new medical technologies: intersections of inquiry. Cambridge University Press.

Lupton, D., 1999. Risk. London: Routledge.

Machado, H., 2008. Biologising paternity, moralising maternity: the construction of parenthood in the determination of paternity through the courts in Portugal. Feminist Legal Studies, 16 (2), 215-236.

Machado, H. and Silva, S., 2008. A Portuguese perspective. Commentary on the Nuffield Council on Bioethics Report "The forensic use of bioinformation: ethical issues”. Biosocieties, 3 (1), 99-101.

Marx, G., 2006. Soft surveillance: the growth of mandatory volunteerism in collecting personal information - "Hey buddy can you spare a DNA?". In: T. Monahan, ed. Surveillance and security: technological politics and power in everyday life. New York: Routledge, 37-56.

Marx, K., 1995 [1867]. Capital I. Marx/Engels Internet Archive (marxists.org) [online]. Available from: http://www.marxists.org/archive/marx/works/1867-c1/index.htm [Accessed 23 May 2008].

Mauss, M., 1954. The gift: forms and functions of exchange in archaic societies. London: Cohen \& West.

Nash, C., 2004. Genetic kinship. Cultural Studies, 18 (1), 1-33.

Nuffield Council on Bioethics, 2007. The forensic use of bioinformation: ethical issues [online]. Available from: http://www.nuffieldbioethics.org/fileLibrary/pdf/The_forensic_use_of bioinformation___ethical_issues.pdf [Accessed 5 March 2008].

O'Neill, O., 2002. Autonomy and trust in bioethics. Cambridge University Press.

Pálsson, G., 2007. Anthropology and the new genetics. Cambridge and New York: Cambridge University Press.

Pennings, G., 1997. The "double track" policy for donor anonymity. Human Reproduction, 12 (12), 2839-2844.

Phoenix, A., et al., ed., 1991. Motherhood: meanings, practices and ideologies. London: Sage Publications.

Ploeg, I., 2002. Biometrics and the body as information: normative issues of the socio-technical coding of the body. In: D. Lyon, ed. Surveillance as social sorting: privacy, risk, and digital discrimination. London and New York: Routledge, 57-73.

Plows, A. and Boddington, P., 2006. Troubles with biocitizenship? Genomics, Society and Policy, 2 (3), 115-135.

Portuguese Council of Ministers, 2008. Announcement of the Portuguese Council of Ministers of April 24th [online]. Available from: http://www.portugal.gov.pt/Portal/PT/Governos/ Governos_Constitucionais/GC17/Conselho_de_Ministros/Comunicados_e_Conferencias_de_ Imprensa/20080424.htm [Accessed 11 May 2008].

Portuguese Justice Minister, 2007. Public announcement of the law proposal regarding the DNA profiles database [online]. Available from: http://www.portugal.gov.pt/Portal/PT/Governos/ Governos_Constitucionais/GC17/Ministerios/MJ/Comunicacao/Intervencoes/20070601_ MJ_Int_Bases_Dados_Perfis_ADN.htm [Accessed 11 May 2008].

Prainsack, B., 2007. Research populations: biobanks in Israel. New Genetics and Society, 26 (1), $85-103$.

Rabinow, P., 1997. Artificiality and enlightenment: from sociobiology to biosociality. In: P. Rabinow, ed. Essays in the anthropology of reason. Princeton University Press, 91-110.

Rose, H., 2001. Gendered genetics in Iceland. New Genetics and Society, 20 (2), 119-138. 


\section{S. Silva and H. Machado}

Rose, N. and Novas, C., 2005. Biological citizenship. In: A. Ong and S. Collier, eds. Global assemblages: technology politics and ethics as anthropological problems. Oxford: Blackwell, 439-463.

Sheldon, S., 2005. Reproductive technologies and the legal determination of fatherhood. Feminist Legal Studies, 13 (3), 349-362.

Silva, S., 2008. Consentir incertezas: o consentimento informado e a (des)regulação das tecnologias de reprodução assistida. Cadernos de Saúde Pública, 24 (3), 525-534.

Silva, S. and Machado, H., 2008. The diagnosis of infertility: patients' classification processes and feelings. Medical Sociology On-Line, 3 (1), 4-14.

Soini, S., et al., 2006. The interface between assisted reproductive technologies and genetics: technical, social, ethical and legal issues. European Journal of Human Genetics, 14, 588-645.

Thompson, C., 2005. Making parents: the ontological choreography of reproductive technologies. Cambridge: The MIT Press.

Tober, D., 2001. Semen as gift, semen as goods: reproductive workers and the market in altruism. Body \& Society, 7 (2-3), 137-160.

Ulrich, M. and Weatherall, A., 2000. Motherhood and infertility: viewing motherhood through the lens of infertility. Feminism and Psychology, 10 (3), 323-336.

Vayena, E., et al., ed., 2002. Current practices and controversies in assisted reproduction. Geneva: World Health Organization.

Waldby, C., 2000. Fragment bodies, incoherent medicine. Social Studies of Science, 30 (3), 465-475.

Weber, M., 1962. Basic concepts of sociology. New York: Citadel Press.

Williams, G. and Schroeder, D., 2004. Human genetics banking: altruism, benefit and consent. New Genetics and Society, 23 (1), 89-103.

Williams, R. and Johnson, P., 2004. Wonderment and dread: representations of DNA in ethical disputes about forensic DNA databases. New Genetics and Society, 23 (2), 205-223.

Williams, R., Johnson, P., and Martin, P., 2004. Genetic information and crime investigation. [online]. Available from: http://www.dur.ac.uk/resources/sass/sociology/Genetic\%20Information $\%$ 20\&\%20Crime\%20Investigation.pdf [Accessed 8 October 2007]. 